\title{
Factors that Affect Prognosis and Morbidity in Pediatric Patients with Carbon Monoxide Poisoning
}

\author{
Karbonmonoksit Zehirlenmesi Olan Çocuk Hastalarda Prognoz ve Morbiditiye Etkileyen \\ Faktörler
}

\author{
(1) Yılmaz Seçilmiş ${ }^{1}$, (1) Mehmet Adnan Öztürk² \\ 1 Erzurum Regional Training and Research Hospital, Clinic of Pediatrics, Erzurum, Turkey \\ 2Erciyes University Faculty of Medicine, Department of Pediatrics, Division of Pediatric Emergency, Kayseri, Turkey
}

\section{Abstract}

Introduction: Carbonmonoxide poisoning continues to be a major health problem worldwide, especially in developing countries, and constitutes an important part of the patients admitted to the pediatric emergency clinics due to poisoning. The aim of this study was to evaluate the correlation between clinical severity, morbidity, hospital stay, intensive care need, and full systemic effects in patients who were followed up and treated for carbon monoxide poisoning in our pediatric emergency clinic.

Methods: The study was performed between January 2013 and 2015. We included patients under 18 years of age who were admitted to the pediatric emergency with carbon monoxide poisoning. Assessments were made prospectively. The epidemiological characteristics, complaints, physical examination and vital findings of all patients were recorded. Carboxyhemoglobin ( $\mathrm{COHb})$ level, oxygen saturation, electrocardiography, complete blood count, liver and kidney functions, and cardiac enzymes were studied, and Glasgow Coma scale (GCS) was calculated.

Results: The mean length of hospital stay for 232 patients was calculated as $7.08 \pm 1$ hours and the mean duration of exposure to carbon monoxide gas was $3.17 \pm 2.5$ hours. Higher $\mathrm{COHb}$ levels and cardiotoxicity were detected in patients with a longer duration of exposure and a lower GCS and an increased intensive care need $(p<0.01)$. There was no correlation between $\mathrm{COHb}$ levels and clinical severity, GCS, or intensive care unit need. However, it was found that high $\mathrm{COHb}$ levels (especially above 30\%) increased cardiac injury and neurological symptoms but did not cause a permanent sequela $(p<0.05)$. None of the patients had permanent neurological, cardiac, or renal damage.

Conclusion: We found that duration of exposure is the most important and accurate parameter for the evaluation of clinical course and morbidity. In patients with high $\mathrm{COHb}$ levels, the effects are more prominent, however, we considered that there was no change in sequelae at long-term follow up.

Keywords: Carbon monoxide, carboxyhemoglobin, morbidity, pediatric emegency, poisoning

\section{Öz}

Giriş: Karbonmonoksit zehirlenmesi başta gelişmekte olan ülkelerde olmak üzere tüm dünyada önemli bir sağlık problemi olmaya devam etmekte ve zehirlenme nedeniyle çocuk acil servislerine başvuran hastaların önemli bir bölümünü oluşturmaktadır. Bu çalışmanın amacı, çocuk acil servisimizde karbonmonoksit zehirlenmesi nedeniyle takip ve tedavi edilen hastalarda klinik şiddet, morbidite, hastanede kalış süresi, yoğun bakım ihtiyacı ve sistemik etkiler arasındaki ilişkiyi araştırmaktır.

Yöntemler: Çalışmaya karbonmonoksit zehirlenmesi ile başvuran çocuk acile başvuran 18 yaş altı 232 çocuk dahil edildi. Değerlendirme ileriye yönelik olarak yapıldı. Tüm hastaların epidemiyolojik özellikleri, şikayetleri, fizik muayene ve yaşamsal bulguları kaydedildi. Karboksihemoglobin düzeyi, oksijen satürasyonu, elektrokardiyografi, tam kan sayımı, karaciğer ve böbrek fonksiyonları, kardiyak enzimler çalışıldı ve Glasgow Koma skoru (GKS) hesaplandı.

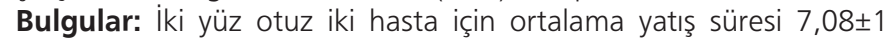
saat olarak hesaplandı ve ortalama karbonmonoksit gazına maruz kalma süresi $3,17 \pm 2,5$ saat olarak hesaplandı. Daha uzun süre maruz kalan hastalarda daha yüksek karboksihemoglobin düzeyleri ve kardiyotoksisite, azalmış GKS ve artmış yoğun bakım ihtiyacı saptanmıştır $(p<0,01)$. Karboksihemoglobin düzeyleri ile hastanın klinik şiddeti, GKS ve yoğun bakım ihtiyacı arasında korelasyon yokken $(p>0,05)$ özellikle \%30 ve üzeri seviyelerde kardiyak ve nörolojik hasarı artırdığı saptanmıştır. Hiçbir hastada kalıc nörolojik, kardiyak veya renal hasar gelişmedi.

Sonuç: Karbonmonoksit gazına uzun süre maruz kalmanın morbiditeyi artırdığını ve diğer epidemiyolojik, klinik ve laboratuvar parametrelerine önemli bir etkisi olmadığını ve yüksek orandaki karboksihemoglobin seviyelerinde organ etkileniminin belirginleştiği ancak sekel değişiklik bırakmadığını değerlendirdik.

Anahtar Kelimeler: Karbonmonoksit, karboksihemoglobin, morbidite, çocuk acil, zehirlenme

Address for Correspondence/Yazışma Adresi: Yılmaz Seçilmis MD, Erzurum Regional Training and Research Hospital, Clinic of Pediatrics, Erzurum, Turkey E-mail: yildosec@hotmail.com

Received/Geliş Tarihi: 09.07.2018 Accepted/Kabul Tarihi: 12.10.2018

- Copyright 2018 by Society of Pediatric Emergency and Intensive Care Medicine

Journal of Pediatric Emergency and Pediatric Intensive Care published by Galenos Yayınevi. 


\section{Introduction}

Carbon monoxide poisoning continues to be a major health problem worldwide, especially in developing countries. ${ }^{1}$ It constitutes an important part of those patients who are admitted due to poisoning to pediatric emergency clinics. ${ }^{2,3}$ Especially during the winter months, coal stoves which are not adequately maintained, fires, and water heaters are the most common sources. Carbon monoxide rapidly binds to the iron atom in the hemoglobin structure when taken into the body and forms carboxyhemoglobin (COHb). ${ }^{3}$

Although all organs in the body can be affected, brain and heart are affected most. ${ }^{4}$ Myocardial ischemia, tachycardia, or bradycardia and hypotension may occur in the cardiovascular system. Electrocardiography (ECG) findings include dysrhythmia, T and ST segment changes. ${ }^{5-7}$ In the central nervous system, complaints can be seen in the spectrum ranging from headache to coma. Rarely, rhabdomyolysis and renal insufficiency can be seen clinically in severe cases.8,9 Diagnosis is based on medical history, physical examination, and $\mathrm{COHb}$ level. Hyperbaric oxygen therapy (HBOT) can be applied in severe cases in addition to oxygen and supportive therapy. ${ }^{10,11}$

Although extensive studies have been carried out on patients who were admitted to adult emergency clinics, the general literature is very limited in children.

In this study, we aimed to evaluate the correlation between clinical severity, morbidity, length of hospital stay, intensive care need, and full systemic effects, especially cardiac and neurological toxicity, and laboratory parameters in patients who were followed up and treated for carbon monoxide poisoning in our pediatric emergency clinic.

\section{Materials and Methods}

The study was performed prospectively and was approved by Erciyes University Ethics Committee (2014/510). The study was commenced in 1 January 2013 and completed in 22 January 2015. The patients were diagnosed and identified according to history, physical examination, and laboratory analysis, and were then included in the study. Patients who could not be diagnosed clearly, whose history was incomplete or suspicious, and who did not meet the poisoning criteria were excluded. All patients who were diagnosed with emergency carbonmonoxide poisoning or diagnosed in the emergency room were included in the study. Patients, who received treatment at another clinic, who had chronic diseases, and who died, were excluded from the study. Symptoms, physical examination findings, vital signs and oxygen saturation values were recorded. The duration of hospital stay was recorded for each patient. When this period was calculated, the time that the patient was followed in the emergency room was taken into consideration.

Similarly, tests to determine complete blood count, liver and renal functions, serum electrolytes, creatine kinase, creatine kinase-MB (CK-MB), troponin, and COHb levels as well as ECG were performed in all patients. Reference values are based on institutional biochemical laboratory references. According to GCS, it was determined whether there was a need for followup in the intensive care unit. All patients were followed closely by monitoring their vital signs.

\section{Statistical Analysis}

The Statistical Package for the Social Sciences (SPSS) version 21.0 was used for data analysis. Mean, median and standard deviation values were calculated by using recorded patient data. The Kolmogorov-Smirnov test was used to determine whether the dependent variables were normally distributed. The Mann-Whitney $U$ test was used for the analysis of two independent groups which did not have normal distribution. The linear relationship between two continuous variables was analyzed using the Spearman's Rho test. The chi-square test was used to evaluate the relationship between two categorical variables.

\section{Results}

A total of 232 patients in various age groups (1-192 months) were enrolled. The mean age of the patients was $83.58 \pm 55$ months. One hundred and five (45\%) patients were female and 127 (55\%) were male. A total of 198 patients (85\%) were recorded as poisoned due to improper or incorrect use of a coal stove, $28(12.5 \%)$ were poisoned by a fire, and $6(2.5 \%)$ were poisoned due to other sources such as water heater and others. There were no statistically significant differences in the liver, kidney, and other biochemical parameters of the patients. The mean duration of hospitalization for 232 patients was $7.08 \pm 2.1$ hours. When epidemiologically evaluated, 20 (8\%) of 232 patients applied to health facilities in the rural area and 202 (92\%) patients applied to health facilities in the urban area (Table 1).

\section{Table 1. Epidemiological parameters}

\begin{tabular}{|ll|} 
Parameter & $\mathbf{n}(\%)$ \\
Gender & \\
Male & $106(45)$ \\
Female & $127(55)$ \\
Carbon monoxide source & \\
$\quad$ Coal stove & $198(85)$ \\
Fire & $28(12.5)$ \\
Others & $6(2.5)$ \\
Arrival place & \\
Rural & $20(8)$ \\
Urban & $22(92)$ \\
\hline
\end{tabular}


The mean duration of exposure to carbon monoxide gas was $3.17 \pm 2.5$ hours. Significance score was calculated as $p<0.01$ of the correlation applied in terms of whether patients who had a longer carbon monoxide gas exposure had higher $\mathrm{COHb}$ levels (correlation coefficient $r=0.780$ ). This value shows that the $\mathrm{COHb}$ level was statistically significantly higher in patients exposed to carbon monoxide gas for a longer duration (Graphic 1). The correlation between the duration of exposure and troponin positivity was also significant $(p<0.01)$.

Statistically significant results were obtained during the analysis in terms of dysrhythmia in patients with a longer carbon monoxide exposure $(p=0.03)$. Similarly, in patients with longer exposure to carbon monoxide a significant relationship was found between intensive care need and GCS score ( $p=0.02$ and $p=0.04$, respectively).

All patients followed up in the emergency room were followed for a minimum of 6 hours and a maximum of 96 hours (for an average of 7.08 hours), depending on the severity of the poisoning, in terms of the possible toxic effects of carbon monoxide. The average $\mathrm{COHb}$ levelwas $17 \% \pm 12.6$.

The reference intervals were taken as $0.3-0.7 \%$ and the patients were evaluated according to $\mathrm{COHb}$ levels. When assessed according to increase in $\mathrm{COHb}$ levels, 25 (10.8\%) patients were in the normal range, $164(70.7 \%)$ were in the $0.7 \%-30 \%$ range, and $43(18.5 \%)$ patients were in the above $30 \%$. At the first physical examination of 232 patients, 189 patients (81.4\%) had a GCS score of 15, $37(15.9 \%)$ had 9-12, and $3(1.3 \%)$ patients had..$^{3.8}$ The number of patients with impaired vital signs and requiring intensive care was 3 $(1.4 \%)$. In these 3 patients, the GCS score was under 3.

When high $\mathrm{COHb}$ levels were evaluated to determine whether they affected GCS scores, no significant relationship was found between GCS score and values above the reference or the levels that gave rise to severe signs in the central nervous system $(p=0.54)$. When $\mathrm{COHb}$ levels were

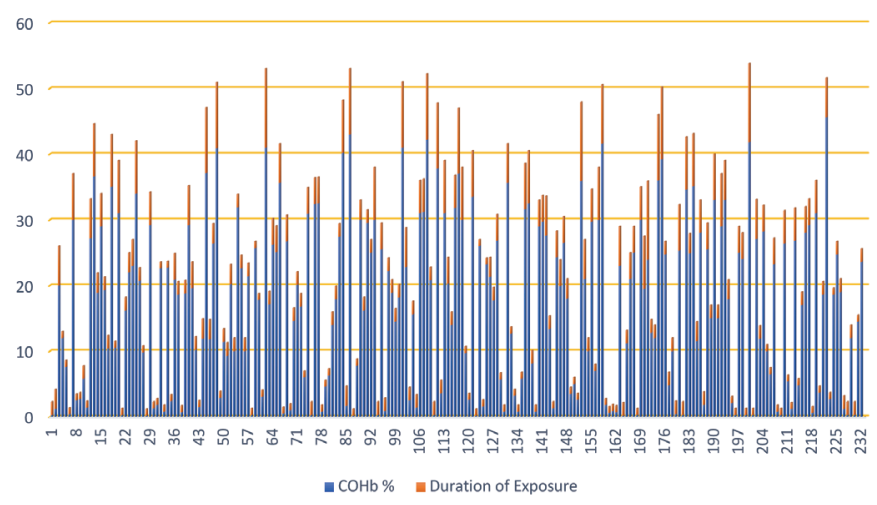

Graphic 1. The relation between carboxyhemoglobin levels and the duration of $\mathrm{CO}$ gas exposure

$\mathrm{COHb}$ : Carboxyhemoglobin

*The duration unit was given as hour, ${ }^{+} \mathrm{COHb}$ unit was given as percentage grouped as normal, high, and very high ( $>30 \%)$, there was no statistically significant difference $(p=0.18)$. All patients were evaluated for saturation at the time of arrival. Saturation values were found over $95 \%$ in $179(77 \%)$, between $92-95 \%$ in $42(18 \%)$, between $80-92 \%$ in $8(3.4 \%)$, and under $80 \%$ in $3(1 \%)$ patients who received intensive care. The mean $\mathrm{COHb}$ levelwas $17 \% \pm 12$. Statistical comparisons were done to evaluate whether high $\mathrm{COHb}$ levels caused hypoxia and it was found that patients with high levels were not more desaturated ( $p>0.05)$. In terms of cardiac toxicity, all patients were followed up by a monitor. ECG findings were obtained in all patients. Sixteen (6.8\%) patients had bradycardia (according to age group percentile), 48 (20.6\%) patients had sinus tachycardia (according to age group percentile) and 168 (72.6\%) patients had no dysrhythmia or other ECG findings. No significant difference was found in the analysis between high $\mathrm{COHb}$ levels and dysrhythmia ( $p>0.33$ ).

Tests to determine creatine kinase, CK-MB and troponin levels were performed in all patients. The reference values for all parameters were based on local laboratory values. Normal ranges were $\leq 171 \mathrm{U} / \mathrm{L}$ for male, $\leq 145 \mathrm{U} / \mathrm{L}$ for female, $0-25$ $\mathrm{U} / \mathrm{L}$ for CK-MB and 0-0.04 $\mu \mathrm{g} / \mathrm{L}$ for troponin. Twenty-eight $(12 \%)$ patients were high in all three parameters. The CK-MB level was high in 120 (51.7\%) and troponin T value was high in $28(12.1 \%)$ patients (Table 2 ).

No significant correlation was found between patients with increased $\mathrm{COHb}$ levels in terms of CK-MB elevation $(p>0.05)$. There was a statistically significant difference between dysrhythmia and high level of troponin $(p=0.015)$. The Pearson's correlation coefficient between these two variables was calculated as $r=0.658$. Troponin levels were statistically significantly higher in patients with high $\mathrm{COHb}$ levels $(p=0.008$ ) (Table 3 ). Twenty-eight patients who had

Table 2. Admission and pre-discharge control carboxyhemoglobin levels and cardiac affect of poisoning

\begin{tabular}{lll|} 
Parameter & Arrival $\mathbf{n}(\%)$ & Control $\mathbf{n}(\%)$ \\
COHb & & \\
$\quad \begin{array}{l}\text { Normal } \\
\text { High }\end{array}$ & $25(10.8)$ & $81(34.9)$ \\
CK-MB & $207(89.2)$ & $151(65.1)$ \\
$\quad$ Normal & & \\
$\quad$ High & $112(48.3)$ \\
Troponin & $120(51.7)$ \\
$\quad$ Negative & \\
$\quad$ Positive & $204(87.9)$ \\
EKG & $28(12.1)$ \\
$\quad$ Normal & \\
$\quad$ Bradycardia & $168(72.4)$ \\
Tachycardia & $16(6.9)$ \\
Total & $48(20.7)$ \\
COHb: Carboxyhemoglobin, CK-MB: Creatine kinase, ECG: Electrocardiography \\
\hline
\end{tabular}


Table 3. Relationship between carboxyhemoglobin levels and vital parameters

\begin{tabular}{|c|c|c|c|c|c|}
\hline \multirow[b]{2}{*}{ Parameter } & \multirow[b]{2}{*}{ Unit } & \multicolumn{3}{|c|}{ COHb Level } & \multirow[t]{2}{*}{ p } \\
\hline & & $\begin{array}{l}\text { Normal }(0.3-0.7 \%) \\
(n=27)\end{array}$ & $\begin{array}{l}\text { Medium height }(0.7-30 \%) \\
(n=164)\end{array}$ & $\begin{array}{l}\text { Very high }(>30 \%) \\
(n=41)\end{array}$ & \\
\hline GCS & Score & $13.5 \pm 2$ & $14 \pm 2$ & $14 \pm 1.8$ & 0.18 \\
\hline Troponin & $\mu \mathrm{g} / \mathrm{L}$ & $0.02 \pm 0.0 .4$ & $0.07 \pm 0.02$ & $0.02 \pm 0.04$ & 0.008 \\
\hline CK positivity & Percent & 25.9 & 18.3 & 43.9 & 0.003 \\
\hline Dysritmia positivity & Percent & 22.2 & 26.2 & 36.6 & 0.33 \\
\hline Patients with neurological symptoms & Percent & 11.1 & 16.5 & 65.9 & 0.047 \\
\hline
\end{tabular}

troponin elevation and 64 patients with dysrhythmia had normal control values before discharge. There was no cardiac problem in their follow-up after discharge.

The median value of the creatine kinase test was calculated as 103 to evaluate the effects of muscle carbon monoxide on involvement and rhabdomyolysis. Since there were patients with extreme values in these calculations, the mean and standard deviations are not given. There was no significant relationship between $\mathrm{COHb}$ at high levels for rhabdomyolysis ( $p>0.05)$, however, CK levels were significantly higher in patients with high $\mathrm{COHb}$ levels $(p=0.003)$. When evaluated in terms of neurological symptoms, there were 36 (15.5\%) patients with confusion and 35 (15.1\%) patients with headache. Three (1\%) patients were in coma and were followed up in the intensive care unit. The rest of the 158 (68.1\%) patients did not have neurological symptoms. A statistically significant correlation was found between a high $\mathrm{COHb}$ level and the incidence of neurological symptoms ( $p=0.047$ ). Neurological sequelae were not seen in any patient in the long-term follow-up.

\section{Discussion}

The etiologies of the patients presenting to emergency departments vary because of the variability in socioeconomic levels and lifestyles in each region of the world. In 2008, Cho et al. ${ }^{12}$ conducted a 10-year retrospective analysis of 30 patients in a limited population in Taiwan. They reported that $53.3 \%$ of the patients had poisoning caused by hot water heaters. In our study area, the use of stoves for heating in the winter is quite common, thus, poisoning resulting from the use of stoves constituted the most common etiology in our study. A study by Raub et al. ${ }^{13}$ published in 2000 about carbon monoxide poisoning reported that the most common cause of poisoning in the United States was motor vehicles and industrial gases. This difference is directly related to the level of socioeconomic development of the countries. For this reason, coal-related poisonings are much less common in industrialized countries such as the US than in other countries 13. In 2011, Yurtseven et al. ${ }^{14}$ included 171 adult patients in a retrospective analysis study. Forty-nine (30\%) patients were found to have $\mathrm{COHb}$ levels within the normal

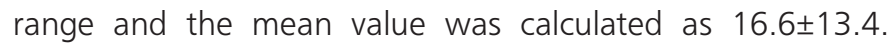
There was no statistically significant relationship between high $\mathrm{COHb}$ levels and clinical severity. In our study, similarly, there was no statistically significant relationship between increased $\mathrm{COHb}$ levels and clinical course and intensive care need ( $p>0.05) .{ }^{14}$ In a declaration published by the Medical Effects Board of the Air Pollution Committee in 2004 and the study conducted by Barker et al. ${ }^{16}$ in 2006, a cut-off value of over 30\% was taken for severe clinical picture. Similarly, in our study, because serious neurological symptoms arose, the cut-off value was $30 \% .^{15}$ The number of patients over this value was 43 (18.5\%). The $\mathrm{COHb}$ value was found to be over $30 \%$ in 27 of 36 patients who were detected to have confusion on admission as a clinical manifestation. As $\mathrm{COHb}$ levels increased, there was a statistically significant increase in neurological symptoms ( $p=0.047)$.

According to the evaluation of the levels of oxygen-free saturation measured at the time of admission, we concluded that an increased level of $\mathrm{COHb}$ did not significantly affect saturation level $(p>0.05)$. However, the pulse oximeter we use works according to the Beer-Lambert law and the light is not absorbed outside a certain wavelength, but $\mathrm{COHb}$ absorbs the wavelength of the light that the device is working on. Therefore, the measured normal values do not always reflect the true value. ${ }^{16}$

Carbon monoxide poisoning causes cardiac damage ranging from mild to severe. ${ }^{17}$ Dysrhythmia, $T$ wave abnormalities, and ST segment changes are the most common findings. ${ }^{18}$ In a study by Deniz et al. ${ }^{19}$ in 106 patients, T wave negativity was found in $11.3 \%$ of cases, sinus tachycardia in $26.4 \%$, ST change in $10.4 \%$, and normal ECG in the remaining $66 \%$. In a prospective study by Ozyurt et al. ${ }^{20}$ in 22 patients, prolonged Qtc interval was detected in the group with poisoning compared to the control group but no dysrhythmia was observed. In a 3-year prospective analysis of the pediatric 
age group by Teksam et al. ${ }^{21}$ ischemic changes were not detected in any of the patients while sinus tachycardia was detected in $30.5 \%$ of 131 patients. In all three studies, transient echocardiography findings without sequelae were found. Similar to these studies, we found sinus tachycardia in $20 \%$ of all patients in our study. Since dysrhythmia and the other ECG findings returned to normal after discharge with full clinical recovery at the end of the follow-up period in the majority of the patients, echocardiographic assessment was not performed. In long-term follow-up, no permanent cardiac damage was seen in any patient. When patients are assessed for myocardial injury, troponin $T$ value is a more sensitive test for assessing myocardial ischemia and related damage compared to CK-MB value. ${ }^{22,23}$

In a retrospective study involving 141 patients by Huysal et al. ${ }^{24}$ troponin levels were found to be statistically significantly increased in patients with higher COHb levels than CK-MB. As troponin was more significant in terms of cardiac damage, increased $\mathrm{COHb}$ levels were considered as having a stimulant effect in terms of cardiac injury. In a study by Kalay et al. ${ }^{25}$ in a limited patient population (20 patients), a positive correlation was found between high $\mathrm{COHb}$ levels and elevated cardiac enzymes. Similarly there was a correlation between increased $\mathrm{COHb}$ and myocardial injury in our study $(\mathrm{p}=0.008)$. When the ECGs of patients with a high troponin value were examined, it was found that tachycardia was statistically significant in terms of development of dysrhythmias $(p=0.015)$. On the other hand, the study of Kalay et al. ${ }^{25}$ found a significant relationship between higher $\mathrm{COHb}$ levels and cardiotoxicity in patients exposed to carbon monoxide for longer periods of time. In our study, we found that as the duration of exposure to carbon monoxide gas increased, both $\mathrm{COHb}$ levels and cardiotoxicity increased and neurological effects were more common.

Since there are not enough studies in the literature in both adult and pediatric patients, a comprehensive evaluation and comparison could not be made.

The patients were assessed in terms of general parameters such as general condition, vital signs, full consciousness and awareness, GCS, and COHb levels before discharge. The average $\mathrm{COHb}$ level before discharge was $1.25 \%$. No statistically significant difference between was found in patients with high levels of $\mathrm{COHb}(30 \%$ and above) and duration of hospitalization and intensive care need ( $p>0.05$ ). Therefore, the baseline level of $\mathrm{COHb}$ was assessed as having no effect on the duration of hospitalization or the need for further treatment. In contrast to the data that we found in our study, Chang et al. conducted a study including 81 patients between 2002 and 2010 and reported a significant relationship between $\mathrm{COHb}$ levels and morbidity and mortality rates. Twenty-five percent of patients had HBOT and their baseline $\mathrm{COHb}$ levels were found to be statistically significantly higher compared to conventional treatment subjects. ${ }^{26}$

In our study, 3(1.2\%) patients were followed up in the intensive care unit and these patients did not have a significantly higher $\mathrm{COHb}$ level compared to the other conventional treatment group. These 3 patients received conventional mechanical ventilation therapy and all three recovered without sequelae without taking HBOT. In their 3-year study, Icme et al. ${ }^{27}$ found that $\mathrm{COHb}$ levels were higher in patients who had a GCS score below. ${ }^{15}$ As a result, a negative correlation between $\mathrm{COHb}$ and GCS was found. ${ }^{27}$ In their retrospective study including 173 patients, Grieb et al. ${ }^{28}$ reported that there was a negative correlation between $\mathrm{COHb}$ levels and GCS; they found that the neurological status of the patients improved with the elevation of $\mathrm{COHb}$ levels or increased GCS scores. Our study used an objective criterion such as GCS and, unlike these two studies, no significant relationship was found between the $\mathrm{COHb}$ levels and GCS.

\section{Study Limitation}

The limitations of our work include its single-center nature and possibility of some missed patients.

\section{Conclusion}

As a result, carbon monoxide poisoning is still an important cause of admission in pediatric emergency clinics in developing countries where coal and similar fuels are used for heating.

In our study, we found that the most important parameter to assess the prognosis and morbidity in children was the duration of exposure. Taking into account the clinical features and laboratory findings of children who were exposed to carbon monoxide poisoning, we found that the duration of exposure was the most important and accurate parameter for the evaluation of clinical course and morbidity. However, it was found that high $\mathrm{COHb}$ levels (especially above 30\%) increased cardiac injury and neurological symptoms but did not cause permanent sequela.

\section{Ethics}

Ethics Committee Approval: Erciyes University Ethics Committee, approval number: 2014/510.

Informed Consent: Retrospective study.

Peer-review: Internally peer-reviewed.

\section{Authorship Contributions}

Surgical and Medical Practices: Y.S., A.Ö., Concept: Y.S., A.Ö., Design: Y.S., A.Ö., Data Collection or Processing: Y.S., Analysis or Interpretation: Y.S., A.Ö., Literature Search: Y.S., Writing: Y.S., A.Ö. 
Conflict of Interest: No conflict of interest was declared by the authors.

Financial Disclosure: The authors declared that this study received no financial support.

\section{References}

1. Rose JJ, Xu Q, Wang L, Gladwin MT. Shining a Light on Carbon Monoxide Poisoning. Am J Respir Crit Care Med. 2015;192:114547.

2. Guzman JA. Carbon monoxide poisoning. Crit Care Clin. 2012;28:537-48.

3. Ku C-H, Hung H-M, Leong WC, Chen H-H, Lin J-L, et al. Outcome of patients with carbon monoxide poisoning at a far-East poison center. PloS. 2015;10:e0118995.

4. Fawcett TA, Moon RE, Fracica PJ, Mebane GY, Theil DR, et al. Warehouse workers' headache: carbon monoxide poisoning from propane-fueled forklifts. J Occup Environ Med. 1992;34:125.

5. Guidance of the effects of health of indoor air pollutants. Committee on the Medical Effects of Air Pollutants. In: Health Do (ed.). 2004.

6. Rastelli G, Callegari S, Locatelli C, Vezzani G. Myocardial injury in carbon monoxide poisoning. G Ital Cardiol. 2009;10:227-33.

7. Cha YS, Cha KC, Kim OH, Lee KH, Hwang SO, et al. Features and predictors of myocardial injury in carbon monoxide poisoned patients. J Emerg Med. 2014;31:210-5.

8. Janković SR, Stosić JJ, Vucinić S, Vukcević NP, Ercegović GV. Causes of rhabdomyolysis in acute poisonings. Vojnosanit Pregl. 2013;70:1039-45.

9. Sefer S, Degoricija V, Degoricia V, Bilić B, Trotić R, et al. Acute carbon monoxide poisoning as the cause of rhabdomyolysis and acute renal failure. Acta Med Croatica. 1998;53:199-202.

10. Domachevsky L, Adir Y, Grupper M, Keynan Y, Bentur Y. Hyperbaric oxygen in the treatment of carbon monoxide poisoning. Clin Toxicol. 2005; 43:181-88.

11. Ferri FF, Heikki EN, Runyon MS. Carbon mononoxide poisoning. In: First Consult. First Consult, Elsevier, 2006.

12. Cho $\mathrm{CH}$, Chiu NC, Ho CS, Peng CC. Carbon Monoxide Poisoning in Children. Pediatr Neonatol. 2008;49:121-25.

13. Raub JA, Mathieu-Nolf M, Hampson NB, Thom SR. Carbon monoxide poisoning-a public health perspective. J Toxicol. 2000;145:1-14.
14. Yurtseven S, Arslan A, Eryigit U, Gunaydin M, Tatli O, et al. Analysis of patients presenting to the emergency department with carbon monoxide intoxication. Turk J Emerg Med. 2015;15:159-62.

15. Committee on the Medical Effects of Air Pollutants. In: Health Do e. Guidance of the effects of health of indoor air pollutants, 2004.

16. Barker SJ, Curry J, Redford D, Morgan S. Measurement of Carboxyhemoglobin and Methemoglobin by Pulse OximetryA Human Volunteer Study. Anesthesiology. 2006;105:892-97.

17. Satran $\mathrm{D}$, Henry $\mathrm{CR}$, Adkinson $\mathrm{C}$, Nicholson $\mathrm{Cl}$, Bracha $\mathrm{Y}$, et al. Cardiovascular manifestations of moderate to severe carbon monoxide poisoning. J Am Coll Cardiol. 2005;45:1513-16.

18. Weaver LK. Carbon monoxide poisoning. Crit Care Med. 1999;15:297-317.

19. Deniz T, Kandis H, Eroglu O, Güneş H, Saygun M, et al. Carbon monoxide poisoning cases presenting with non-specific symptoms. Toxicol Ind Health. 2016.

20. Ozyurt A, Karpuz D, Yucel A, Tosun MD, Kibar AE, et al. Effects of acute carbon monoxide poisoning on ECG and echocardiographic parameters in children. Cardiovasc Toxicol. 2016:1-9.

21. Teksam O, Gumus P, Bayrakci B, Erdogan I, Kale G. Acute cardiac effects of carbon monoxide poisoning in children. Eur J Emerg Med. 2010;17:192-96.

22. Sheehan $\mathrm{P}$, Vasikaran $\mathrm{S}$. The evolving clinical role of cardiac troponins and new acute myocardial infarction guidelines: Implications for the clinical laboratory. Clin Biochem Rev. 2001;22:53-65.

23. Ross G, Bever FN, Uddin Z, Hockman EM. Troponin I sensitivity and specificity for the diagnosis of acute myocardial infarction. J Am Osteopath Assoc. 2000;100:29-31.

24. Huysal K, Budak YU, Aydin U, Demirci H, Turk T, et al. COHb Level and High-Sensitivity Cardiac Troponin T in 2012 in Bursa, Turkey: A Retrospective Single-Center Study. Iran Red Crescent Med J. 2016;18.e27061

25. Kalay N, Ozdogru I, Cetinkaya Y, Eryol NK, Dogan A, Gul I, et al. Cardiovascular effects of carbon monoxide poisoning. Am J Cardiol. 2007;99:322-24.

26. Chang $Y-C$, Lee $H-Y$, Huang $J-L$, Chiu $C-H$, Chen $C-L$, et al. Risk factors and outcome analysis in children with carbon monoxide poisoning. Pediatr Neonatol. 2017;58:171-77

27. Icme F, Kozaci N, Ay M, Avci A, Gumusay U, Yilmaz M, et al. The relationship between blood lactate, carboxy-hemoglobin and clinical status in CO poisoning. Eur Rev Med Pharmacol Sci. 2014;18:393-97.

28. Grieb G, Simons D, Schmitz L, Piatkowski A, Grottke O, et al. Glasgow Coma Scale and laboratory markers are superior to $\mathrm{COHb}$ in predicting CO intoxication severity. Burns. 2011;37:610-5. 